\title{
From Subsistence to Commercial Hunting: Technical Shift in Cynegetic Practices Among Southern Cameroon Forest Dwellers During the 20th Century
}

\author{
Edmond Dounias ${ }^{1,2}$
}

\begin{abstract}
Tropical rainforest dwellers, who are currently engaged in bushmeat trade, used to track game for their own subsistence. We investigate the technical evolution over the past century of bushmeat procurement by the Fang, a group of southern Cameroon forest dwellers who are renowned for their extensive cynegetic expertise. This investigation consists of a diachronic approach to assess Fang hunting and trapping technology by comparing firsthand data on bushmeat procurement collected in the early 1990s with detailed descriptions recorded in the early 1900s among the same populations by the German anthropologist Günter Tessmann. Other archive sources bequeathed by explorers in the twilight of the 19th century are also exploited. The comparison conveys a more dynamic view of hunting practices following the greater involvement of the Fang hunters in the bushmeat trade. Historical sources remind us that projectile weapons were initially destined for warfare and that trapping, mobilizing a vast panel of modalities, was the prominent means to catch game for domestic consumption. Net hunting and crossbow hunting, which used to be typical Fang activities, are now exclusively conducted by Pygmies; spear hunting with hounds has become anecdotal. If a large range of trap mechanisms is still functional, effort is now focused on snares, elicited by the banalization of twisted wire cable. The legacy of other remaining models is left to children who carry out a didactic form of garden trapping. The major detrimental change is the use of firearms, which were initially adopted as a warfare prestige attribute before becoming the backbone instrument of bushmeat depletion. Revisiting the past provides useful lessons for improving current hunting management, through the promotion of garden hunting and wildlife farming, and the revitalization of a collective and cultural art of hunting as an alternative to indiscriminate overhunting by neophyte and increasingly individualistic hunters.
\end{abstract}

Key Words: bushmeat trade; Cameroon; diachronic comparison; Fang; Günter Tessmann; historical archives; hunting; rainforest; subsistence hunting

\section{INTRODUCTION}

Hunting has always been a subsidy from nature for tropical rainforest inhabitants who originally tracked game for their own subsistence and in a relatively sustainable way. Forest dwellers persist in attributing paramount dietary, cultural, and symbolic values to bushmeat. These values remain strong among urban dwellers, who greatly praise bushmeat and thus sustain a high market demand.

Over the past three decades, the worldwide exponential regression of wildlife has become a justified source of growing apprehension (Redford 1992, Chardonnet 1995, Moulton and Sanderson 1999, Robinson and Bennett 2000, Reynolds et al. 2001). Throughout the tropics in general, and in the tropical rainforests in particular, excessive hunting pressure exerted on forest fauna, mostly for the procurement of bushmeat, has drastically undermined the fate of rainforest biodiversity, adding one more threat to the heavy list of drivers of soaring deforestation (Fimbel et al. 2001, Meijaard et al. 2005). In this context, studies on bushmeat trade have gained a legitimate increasing interest (Nasi et al. 2011), as described in this issue of Ecology and Society. Deep rooted tradition, high market demand, low investment activity, counterproductive conservationist repression, poor education, pervasive poverty, complicit governance, that is, all the ingredients were met for a tragedy-of-the-commons explosive cocktail on a resource that has been treated as convertible rather than renewable (Redmond et al. 2006). Scientists and conservationists have been deploying consistent and concerted efforts to try and quantify the magnitude of the bushmeat trade phenomenon (Bakarr et al. 2001). Most pessimistic estimates on the ongoing fauna depletion are now supported by solid datasets, at least for terrestrial vertebrate; data are still dramatically lacking for aquatic fauna and invertebrates.

Over the past decade, the bushmeat crisis has undergone a dramatic acceleration. The current "bushmeat chain reaction", an adequate formula to be credited to Nelleman et al. (2010), takes advantage of the totally uncontrolled and insecure context throughout the Congo Basin. War, dubious governance, anarchically expanding infrastructure building (for hydroelectric production, fossil fuel extraction, logging, and mining), and demographic explosion have considerably intensified the demand for bushmeat by densely populated settlements that are now immediately concentrated within wildlife habitats. Refugees, soldiers, miners, traders, poachers, and migrants have generated a sprawling market that absorbs several million metric tons of bushmeat annually (Wilkie and Carpenter 1999, Fa et al. 2002). Heavy weapons are now used for killing large mammals (great apes, elephants, large antelopes) to illegally supply in meat these boomtowns flourishing in the middle of nowhere. The bushmeat crisis has progressively become just one sad facet of a gigantic kaleidoscope of all kinds of trafficking (drug, prostitution, gold/ diamond/coltan mining, illegal logging, etc.), which give rise to modern forms of abject human exploitation and abuses perpetrated by local mafias and militias. The traditional hunters who were still the major suppliers of bushmeat trade only two decades ago are now put on the back burner of a savage game that involves new categories of fearless and ruthless actors who are totally out of the scope of this article. 
Our goal is to look back into the less recent past and to reconsider the transition from subsistence to commercial hunting among traditional hunting communities of the Congo Basin. Very few studies have considered the major technical changes that have accompanied this fairly recent shift from subsistence hunting to commercial hunting. One reason for this gap in knowledge is the scarcity of old data describing hunting practices with sufficient detail to sustain a diachronic comparison. Even more difficult to find are descriptions dating back to times when hunting activities were exclusively dedicated to subsistence among societies that nowadays are heavily engaged in bushmeat trade. We aim to attempt such a comparison by taking advantage of unique and detailed ethnographic materials about bushmeat procurement that were successively collected in the same location, that is, southern coastal Cameroon, among the same ethnic group, the Fang, over an interval of 85 years.

The major role played by firearms and cable snares in the intensification of bushmeat procurement for trade has been widely reported (Infield 1988, Colell et al. 1994, Fa 2000, Kümpel et al. 2008, Noss 2008, Sakanashi 2011) and is not specific to the Congo Basin (for instance, cf. Hames 1979, Yost and Kelley 1983, Grenand 1995 and Greaves 1997 for Latin America, as well as Rambo 1978 and Dwyer 1983 for Southeast Asia), but the technical predispositions to this shift and the contextual adoption of these instruments are poorly evoked in the literature. Although the historical perspective of this article will certainly not help stop the current slaughter, it seems useful to keep a formal trace of how the technical change in hunting modalities took place among traditional hunters before the bushmeat crisis became the acute issue that we face today.

\section{METHODS}

The Bantu people referred to as "Fang" in this article constitute a continuum of five ethnic groups, namely the Fang sensu stricto, the Mvae, the Nzaman, the Ntumu, and the Okak. These groups all speak a fang language and form the five infra-groups of the A75 fang linguistic group (Guthrie 1967) that is characterized by a mutual comprehension among speakers of the distinctive infragroups. The Fang populations total around 40,000 in the southern part of Cameroon and are scattered widely and mixed with other linguistic groups over a province covering 47,000 square $\mathrm{km}$ (Fig. 1). Fang populations in Equatorial Guinea and northern Gabon are estimated around 55,000 and 150,000 people respectively. The expertise in bushmeat procurement could easily be extended to the whole Pahouin, pronounced "Pangwe" in German (Nekes 1875, Tessmann 1913), civilization, a linguistic supra-group of nearly one million people encompassing the Bulu, Beti, and Fang ethnic groups (Alexandre and Binet 1958). The Fang are basically slash-and-burn swiddeners who also hunt, trap, and fish. Their main source of cash income is ensured by the sales of bushmeat and freshwater fish (Dounias 2000), food crops surplus (Dounias 1996a, 1996b), and cocoa and coffee as cash crops (Dounias and Hladik 1996). Before colonial times that began during the second half of the seventeenth century, the Fang ethnic groups were widely known as fierce and nomadic warriors who originated east of their current territory near the source of the Ntem and Ivindo rivers. Their migrations were motivated by a secular movement toward the Atlantic coast in search of salt (Alexandre 1965). Fang migrations were a part of a much broader Pahouin migration that occurred as diffuse and irregular step-by-step jumps of extended family groups, which punctuated their progression with local and repeated skirmishes (Chamberlin 1978). The Pahouin migration was interrupted by the colonial penetration from the coast during the second half of the seventeenth century (Bostoen et al. 2015). This presence of new outsiders was the starting point of the involvement of the Pahouin in the trade of forest resources like ivory and copper, but also as raiders of potential slaves (Dounias and Leclerc 2006). In the early twentieth century that corresponds to the period of the first set of observations considered, the bellicose migrations of the Pahouin were vigorously forced to an end by the German administration. This imposed pacification resulted in the sedentarization of the Fang communities in permanent roadside resettlements that were decided by the colonial administration in order to canalize massive enrollment in construction and agro-industrial projects. Sedentarization induced a profound alteration of land use strategies, including a massive adoption of cocoa trees as a means of rapidly establishing control over forestland in this unprecedented context of land pressure (Assoumou 1977). As we will further stress, the modalities of bushmeat procurement were also significantly affected by this abrupt halt in migration and related settlement habits.

Fig. 1. Fang populations and study areas in southern Cameroon

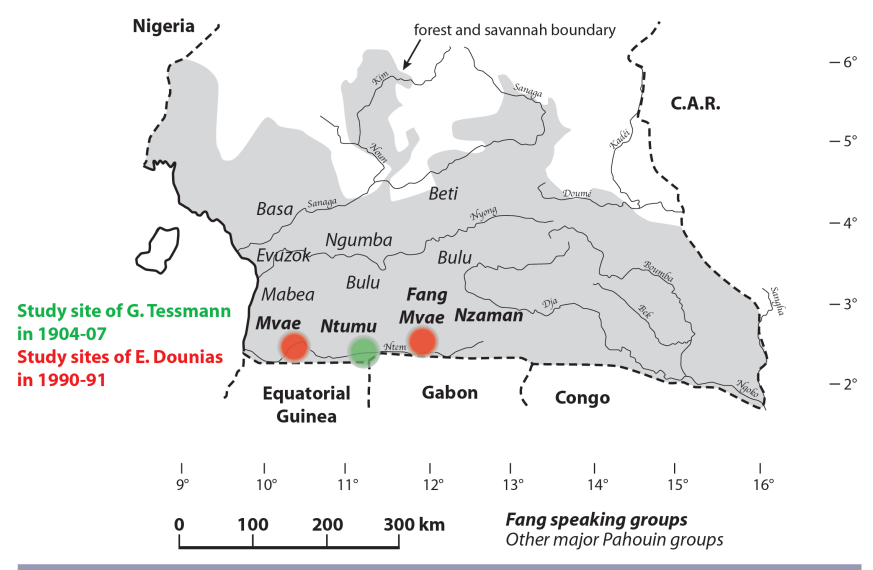

The study area is covered by a mosaic of evergreen and semideciduous rainforests in which the Caesalpiniaceae family predominates. It is home for a remarkable faunal richness that justified that the entire area of Campo district was decreed a faunal reserve as early as in 1932. In the late 1990s, the reserve was downgraded along with the establishment of a broader protected area, the Campo-Ma'an National Park (http://www. parcdecampomaan.com). The Park is a host for 390 species of invertebrates, 249 species of freshwater fishes, 80 species of large and medium sized mammals, 122 species of reptiles, and 302 species of birds. The climate type is four-seasons equatorial; the average annual rainfall exceeds $2,500 \mathrm{~mm}$ and is distributed over 145 rainy days and the mean monthly temperature is $25.6 \mathrm{C}^{\circ}( \pm 3.3$ $\mathrm{C}^{\circ}$ ).

The main historical and ethnographic source that made this diachronic comparison possible is a credit to Günter Tessmann (1884-1969) (Fig. 2). Tessmann was a tireless German explorer, collector, and author who traveled in Cameroon, Spanish Guinea 
(currently Equatorial Guinea), and Gabon between 1904 and 1909, collecting many Fang objects on behalf of the museum of his hometown Lübeck, to which he donated his complete collection. Initially trained as a botanist and zoologist, Tessmann developed a growing interest in anthropology. His most achieved publication is a two-volume monograph on the Pahouin people, first released in 1913. This outstanding book is abundantly illustrated with drawings and photographs by Tessmann himself, and explores many aspects of Pahouin culture, language, history, religion, arts, ecology, and art of war. It includes a yet unequalled description of trapping activities.

Fig. 2. Portrait of Günter Tessmann in 1906. (C) Völkerkundesammlung der Hansestadt Lübeck

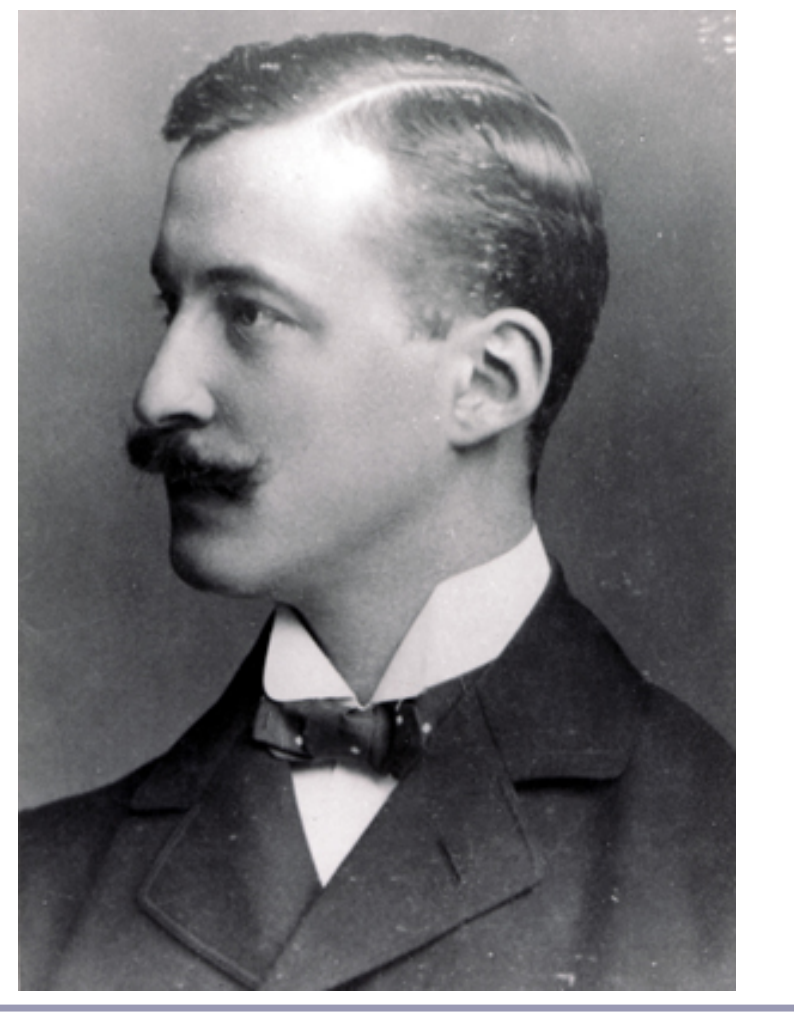

The recent ethnographic source is our own credit and corresponds to our doctoral fieldwork carried out among the Mvae and Ntumu Fang subgroups and their non-Fang neighbors (Yassa coastal fishermen and Kola Pygmies) between 1984 and 1991. To complement ethnographic materials focusing on the subsistence livelihoods and the food systems of these forest peoples, we undertook a quantitative survey of game harvesting in a Mvae village located in the middle of the current Campo-Ma'an National Park. From May 1990 to June 1991, all the prey captured by the 14 hunters of the village were registered, with detailed information about the species (gender, adult, or young), date, location and modality of capture, eventual treatment (fresh, smoked, salted), and destination of the meat (consumed by the hunter and his family versus all kinds of transactions). Over the 13-month period of observation, the 14 hunters killed 2,093 prey belonging to 57 different animal species. The total biomass obtained approximated 15.9 tons. The selected village was fairly small, being composed of 60 permanents inhabitants and 28 temporary residents, including 28 children below the age of 15 years old (Fig. 3) but the totality of hunters accepted to take part in this extensive survey. This unanimous participation within the same village authorized a detailed analysis of the social and cultural drivers of food transactions between villagers, which have been publicized elsewhere (Dounias 1993, 1996a, 2000, Dounias and Bahuchet 2000).

Fig. 3. Synthesis of the bushmeat procurement quantitative survey carried out in a Fang village in 1990-91. Percentages of total biomass captured

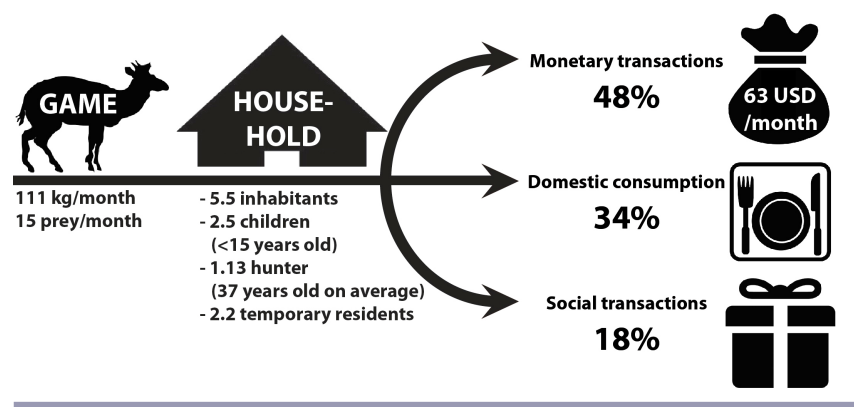

Other studies on local bushmeat procurement were carried out more recently in the subregion. Nevertheless they considered nonFang ethnic groups (Trenning 1998), they addressed Fang communities that are geographically too distant from the site documented by Tessmann, such as on Bioko island (Fa et al. 2000, 2002), in continental Equatorial Guinea (Keylock 2002, Kümpel et al. 2008, 2010) or in Central Cameroon (Sakanashi 2011), or they do not document the technical aspects of hunting procedures (Wolfe et al. 2004). Their relevance in support of our diachronic comparison is accordingly limited.

\section{COMMENTED RESULTS}

Technical distinction between hunting and trapping is a matter of cultural technology school (Leroi-Gourhan 1945); the former is described as active while the latter is presented as passive. Bahuchet and Pujol (1975) distinguish between direct hunting, which implies a face-to-face encounter between man and game, with indirect hunting, which implies recourse to traps in order to catch the game.

Results will successively consider hunting and trapping practices. Among the former, we are going to segregate collective modalities from individual ones that consist of the use of projectile weapons. Opportunistic and minor forms of animal procurement like hand or machete catching of pangolins, tortoises, tree hyraxes, Nile monitors (Varanus niloticus), and snakes, or slingshot shooting of Guinea fowls and other terrestrial birds, will not be considered here. We assume that their incidence on bushmeat trade remains anecdotal and that they were not subject to significant technological change over the past century.

\section{Communal hunting using spears and dogs}

Collective hunting expeditions were still commonly conducted by the Fang hunters in the early 20th century before they progressively became a Pygmy specialty. These expeditions required a high number of protagonists who did not necessarily 
belong to the same community. In that respect, this collective hunting was primarily motivated by sociopolitical considerations. Collective forms of hunting among the Fang had two characteristic attributes in common: spears and dogs.

\section{Spears and dogs}

Before the massive introduction of firearms in Central Africa during the second half of the 19th century (cf. Firearms section), spears were the prominent weapons of Fang arsenal and were used both for war and hunting purposes. Each Fang warrior possessed two or three spears that he kept with excessive care and exhibited with great pride. Fang spears played a central role in the numerous war rites that are meticulously documented by Tessmann. They are relatively short, that is, $175 \mathrm{~cm}$ in length, and easy to handle; the pole is shaped in light wood and its diameter never exceeds $2 \mathrm{~cm}$. In fact, Fang spears were handy and primarily designed for close combat; they were inefficient as a thrown projectile (Knecht 1997, Cadet 2009). Accordingly, spears were used mainly during net hunting and pursuit hunting with hounds, to deliver the coup de grace to the prey only after that it had been stopped by nets or dogs. As with other war weapons (hatchet, throwing knife, sword and crossbow), spears used to be richly carved and ornamented. The pole was incised with Fang-style shallow grooves made with a specific scraper knife. These rich ornaments strongly contrast with the restrained design of instruments used for productive activities (fishing, hunting, gathering and cultivating). Now that war times belong to the past, spears have lost all their ornamental attributes and ritual values.

Dogs are indispensable auxiliaries that drive out game during collective hunting but they also play a significant role when patrolling trap lines. Fang hunters always fasten a wooden bell around the neck of their dogs to readily locate them. Dogs are highly coveted assets among both Pygmy and non-Pygmy hunting societies throughout Central Africa. Puppies are recurrent in bridewealth transactions and in other social bargaining. Tessmann reports that the acquisition of a dog among the Fang was extremely costly. He also details 14 different remedies destined to increase the sense of smell and aggressiveness of dogs, and describes the specific pharmacopeia that accompanied the different steps of dog training. Although the medicines that we observed in the 1990s significantly differed from those documented by Tessmann, their use for increasing the hunting predisposition of dogs persists and is carried out with wise care.

\section{Net hunting}

After the deployment of a series of individual nets that are tied one to the other following very diverse configurations (Dupré 1982, Sato 1983, Bahuchet 1987, Noss 1995), the area of hunting is encircled by a cohort of beaters who, with the assistance of dogs wearing wooden bells, are in charge of running the game down and driving it into the nets. The animals stopped by the nets will be killed by hunters holding spears and ambushed near the nets (Fig. 4). A net is about $50 \mathrm{~m}$ long and $1.5 \mathrm{~m}$ high. The rope consists of one single twisted strand of spun natural textile fibers of plant material. Manniophyton fulvum (Euphorbiaceae), Dicranolepis spp. (Thymeleaceae), Grewia coriacea (Tiliaceae), Cola semecarpopyhlla (Sterculiaceae), and Rauvolfia macrophylla (Apocynaceae) are the most common fiber plants selected for that purpose. Ungulates make up the largest contingent of net hunting prey. The radical "dzāk" of the generic Fang term "è.dzāk" to
Fig. 4. Fang crossbowman. Hand-carved engraving by Paul Belloni du Chaillu, 1863 (reproduced from open access archives of the French National Library- BNF)

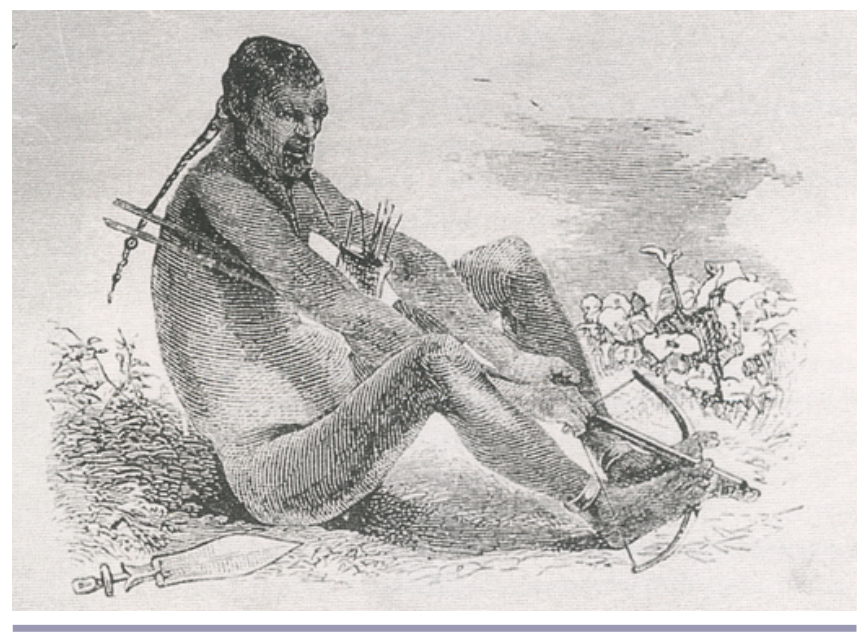

name the various modalities of net hunting, refers to the process of encircling. This term is also used to name Mariscus alternifolius (Cyperaceae), a weed that has the reputation of surrounding and finally smothering crops in the swidden. Setting up such a collaborative activity among the Fang required compliance with numerous social and political prescriptions as well as strict food and sexual prohibitions. Far from being a daily subsistence hunting activity, net hunting was organized very punctually and was primarily aimed at fulfilling political concerns in times of war. Holding a net hunting expedition was an occasion to seal pacts of peace or alliances that were formalized by joint compliance with the prescriptions and prohibitions preceding the hunt, by tight collaboration during the hunt, and ultimately by sharing the prey. Tessmann only briefly evokes this type of hunting, considering it more of a political negotiation process than a mainstream mode of bushmeat procurement. The location of net hunting was not randomly assigned: it had to be carried out in a particular patch of forest named "ò.kày", primarily characterized by its neutral geopolitical position. The ò.kàn has no particular biophysical attributes, but is a portion of forest that marks the junction between two territories, and which is, in essence, considered as "free"; not in the sense that access to this patch of forest would be open (it is in fact strictly codified), but in the sense that no community can claim exclusive ownership over this proxy piece of forest. It is a consensual neutral space where political agreements used to be negotiated (Laburthe-Tolra 1985, Dounias 1993). The selection of an ò.kày had to be decided mutually by the protagonists prior to the net hunting. Today the evocation of the ò.kày persists in oral tradition (tales and proverbs) but has lost any effective socio-political attributes. The last ethnographic reports of net hunting among the Pahouin (Panyella 1959, Koch 1968) suggest that the Fang abandoned this hunting practice in the 1950s. Not surprisingly, Pygmies have become the natural depositories of net hunting since this activity exacerbates egalitarian values like mutual aid, food sharing, social links between communities, spatial mobility and demographic fluidity (Harako 1981, Ichikawa 1983, Sato 1983, Terashima 1983, 
Bahuchet 1987, Bailey and Aunger 1989, Wilkie and Curran 1991, Lupo and Schmitt 2002, Noss 2008). Pygmy women and adolescents participate actively as beaters and transporters, whereas Fang net hunting used to be an exclusive male adult activity. Today, net hunting expeditions by Pygmies are preferably held during the dry season in order to spare the string whose natural fibers are sensitive to excessive humidity. Dry season also coincides with temporary migrations into the forest, in search of wild yam tubers, harvesting of bush mangoes, and the gathering of the favorite Erythrophloeum honey.

\section{Pursuit hunting with hounds}

Pursuit hunting with dogs requires fewer participants than net hunting. It entails a much lesser political dimension, but it remains an efficient means for consolidation of social connections between lineages inside the same village, or between clans from distinct settlements. Brothers-in-law are actively encouraged to pursue game together, and meat sharing follows very subtle cutting procedures that take into consideration the ownership of the dog that caught the prey or of the spear that finished it off. Today, pursuit expeditions with hounds have become anecdotal and are generally carried out in partnership with Pygmy neighbors who continue to excel in this type of hunting (Dounias 1993).

\section{Crossbow}

Historians agree on the highly probable introduction of the crossbow in West Africa by the Portuguese in the 16th century (Roth 1992). This introduction may have initially hit the ancient Kingdom of Benin and spread further south throughout the Congo Basin via the Yoruba (Balfour 1909). The later introduction of a second type of crossbow may explain that two distinctive release devices are concomitantly observed today. Initially, the Fang adopted the crossbow as a war weapon (Fig. 5). Du Chaillu (1856) reports how these warriors buried crossbow darts in the vertical position in the forest undergrowth in order to kill negligent assailants who happened to step on a poisonous head intentionally pointing out from the soil. The primary function of crossbow as a war weapon was reinforced by the preference of crossbowmen for dart poison made of ptomaines collected from the dead bodies of humans, but also of the African giant toad (Amietophrynus superciliaris, Bufonidae), the spotted blind snake (Afrotyphlops punctatus, Typhlopidae), and the fire skink (Lepidothyris fernandi, Scincidae). These animals are embedded in the irrational Fang belief that they can instantly kill humans upon simple contact. Organs of these animals are accordingly used in recipes of criminal/witchcraft talismans and potions (Tessmann 1913, Laburthe-Tolra 1985, Dounias 1993). The use of ptomaines as a hunting poison is strictly avoided because it would make bushmeat totally inedible. The renouncement of ptomaines and their replacement by seeds of Strophantus gratus (Apocynaceae) as the main source of poison mark a turn in crossbow usage from war to hunting weapon, as a direct consequence of the forced pacification initiated by the Germans and continued by the French administration after the First World War. This pacification and the imposed permanent settlement encouraged the preference for a poison that befits human consumption and that can be processed in rather high quantities. The vines of Strophanthus began being commonly "proto-cultivated" in backyard homegardens (Dounias 2010). Nevertheless, crossbows were rapidly superseded by firearms and forsaken to Pygmy hunter-gatherers. Today, Pygmies have become the almost exclusive crossbow users, but are in fact custodians of a hunting technique that they adopted fairly recently. Pygmies do no plant Strophanthus and preferably look for the seeds in nonPygmy abandoned settlements. In the 1980s, the harvesting of Strophanthus seeds even represented a minor extractivist foraging activity that was supported by the pharmaceuticals industry in need of strophantine, a cardiac glycoside that is no longer commercialized (Mbenkum and Thomas 1992).

Fig. 5. Net hunting. Hand-carved engraving by Edouard Riou in Savorgnan de Brazza, 1888 (reproduced from open access archives of the French National Library- BNF)

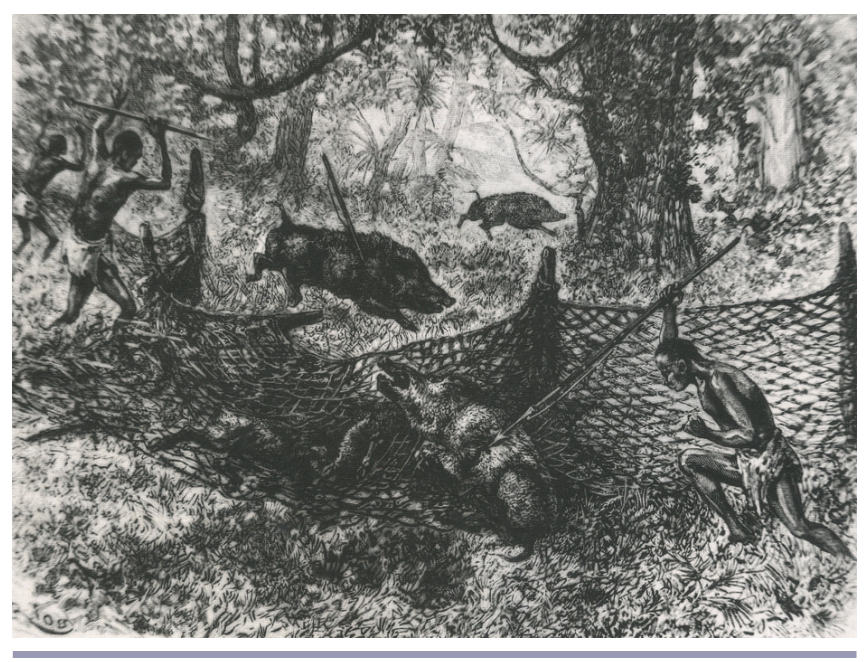

Strophanthus seeds are sometimes admixed with other toxic bases like the latex of Dictyophleba stipulosa (Apocynaceae), the tuber of Dioscorea sansibarensis (Dioscoreaceae), the bark of Zanthoxylum spp. (Rutaceae) or various mushroom adjuvants. The exudate of Palisota hirsuta (Commelinaceae) intervenes as a binder. Crossbow hunting is a diurnal and solitary activity that is conducted mainly at the beginning of the rainy season, when men are less mobilized in farming tasks (tree cutting and field clearing) and when a great number of tree species are fruiting, thus massively attracting frugivorous birds and monkeys (Ohigashi et al. 1987). The fairly short shooting range of the crossbow requires the shooter to get in closer contact with the prey and is accordingly a prerogative of seasoned hunters. They generally have recourse to calling stimuli to attract game and reduce the shooting distance. Whistling in a decoy made of coredout Sapotaceae seeds or shaking leaves of Penianthus longifolius (simulation of the flight of the crowned hawk-eagle Stephanoaetus coronatus, Accipitridae) are common tricks that are used to attract arboreal monkeys.

\section{Firearms}

The first use of firearms in the Congo Basin dates to around 1840 (Savorgnan de Brazza 1888). Muskets and flintkock rifles were massively imported during the 1850s and 1860s (Laburthe-Tolra 1981) and became a popular item in trading posts (Fig. 6), along with pearls, cowrie shells, brass, mirrors, and other products proposed in exchange for forest products (Mboyi Moukanda 2013). These guns were coveted by prestigious warriors and ostentatiously accumulated and brandished as a sign of authority. 
From the beginning of the 1960s, some administrators sounded the alarm about the uncontrolled spread of firearms that rapidly became the main popular war weapon of the Beti and the Fang (Touchard 1861). But these muzzle-loading rifles were still considered inappropriate for hunting. The efficiency of firearms was tenfold increased with the invention of the breech-loading rifle (Fig. 7) that was first used by the French army in 1866. However, these innovative rifles were expensive and it took a couple of decades before they spread out as a trade item. Their use for hunting was initially restricted to the development of colonial business through the massive demand for ivory and other animal remains. Renowned explorers like Paul Belloni du Chaillu, Victor de Compiègne, and Alfred Marche funded their expeditions via this trade and actively armed their hunters, guides, and henchmen for commercial hunting purposes. So did naturalists like Jacques de Brazza, Joseph Cholet, FrançoisRomain Thollon, and Jean Dybowski, who massively shot animals for the purpose of including them in museum collections. At the end of the $19^{\text {th }}$ century, the upsurge of tribal struggles and the difficulties met by the colonial administrations to contain them encouraged a strict regulation of rifle importation and a drastic ban on gunpowder trade. The prohibitive cost of gunpowder significantly delayed the trivial use of firearms for subsistence hunting up to the early 1930s. Another major innovative step in the firearm industry was the replacement of black powder by smokeless powder (Faure 2002), which multiplied by three the shooting distance, thus providing a definitive advantage of shotguns over other projectile weapons. But this change in powder required replacement of copper by brass, tumbaga, or aluminum in the manufacture of gun sockets. The high demand for nonferrous metals to sustain the war effort during the First World War inevitably postponed civil accessibility to this new type of ammunition.

Fig. 6. Trading post. Hand-carved engraving by Louis Breton in Compiègne, 1875 (reproduced from open access archives of the French National Library- BNF)

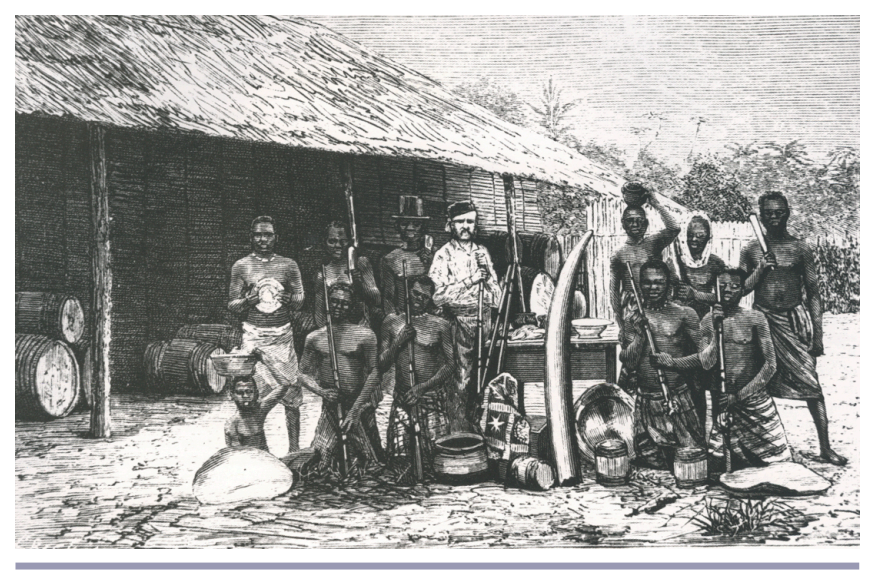

A last but very determining innovation that arose much later on was the democratization of flashlights in the 1970s. They allow shotgun hunting at night, thus transferring the hunting expedition to a vacant time period (with the exception of very seasonal forms of night fishing). Instead of competing with other activities, night hunting with shotguns is an addition. Rather than being an alternative, it becomes a plus. Night hunting is particularly harmful to duikers, which are known for being hypnotized by flashlights. Light reflectance on the retina of nocturnal fauna also facilitates their detection in the darkness and enhances shooting success.

Fig. 7. Photo of the "Chassepot" regulatory breech loading rifle (1866 model) used by the French infantry. Source: https://en. expertissim.com/infantry-rifle-gun-chassepotmodel-1866-1770410

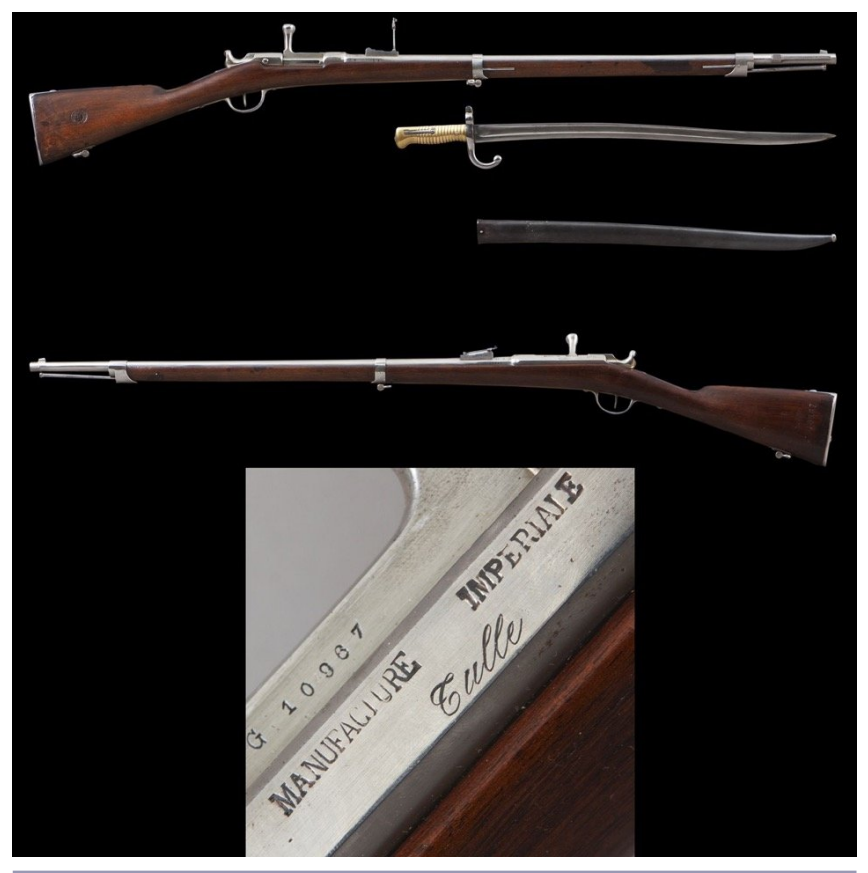

Renouncement of the use of crossbows and induced replacement by firearms has drastically affected the survival of medium-sized arboreal monkeys. Our quantitative survey of bushmeat procurement in 1990-91 revealed that $82 \%$ of the primate biomass (primarily composed of Cercocebus albigena, Cercopithecus nictitans, and Papio sphinx) was obtained with a shotgun. We already evoked the use of calling techniques by crossbow hunters in order to reduce the shooting distance. Whistling in a decoy or shaking leaves are used to provoke the attention of the sole dominant male in a monkey band. When coming into contact with the potential source of danger, this male monkey creates a diversion that allows the rest of the band to flee in the opposite direction. The single death of this male does not impair the persistence of the band. Today, shotgun hunters no longer try to catch the attention of this male. They prefer to take advantage of the increased shooting distance to reach several members of the band indistinctly with a single but scattered buckshot. Such random killings have disastrous consequences on the demographic integrity of the band.

During our 13-month survey in a Mvae village, only three out of the 14 permanent hunters $(21 \%)$ used a shotgun, and none of them were exclusive shotgun users. The shotguns supplied $37 \%$ of the total biomass captured but only $26 \%$ of the total number of prey. Shotguns also contributed to $36 \%$ of the village cash income generated by bushmeat procurement. A total of $58 \%$ of shotgun prey were consumed locally, but these prey added up to only $49 \%$ of the overall bushmeat biomass obtained with 
Table 1. Knowledge and use resilience of Fang traps

\begin{tabular}{|c|c|c|c|c|c|c|c|c|}
\hline \multicolumn{2}{|r|}{ Basic systems $\dagger$} & \multirow[t]{2}{*}{ Types } & \multicolumn{6}{|c|}{ Variants } \\
\hline Code & Description & & $\mathrm{a}$ & $\mathrm{b}$ & $\mathrm{c}$ & $\mathrm{d}$ & $\mathrm{e}$ & Total \\
\hline A & with snare; horizontal release device, on which the prey walks & 7 & 4 & 2 & - & 3 & 1 & 10 \\
\hline $\mathrm{B}$ & with snare; release device and snare are maintained inside a rigid frame & 6 & 6 & - & - & 2 & 2 & 10 \\
\hline $\mathrm{C}$ & $\begin{array}{l}\text { with snare and bait; oblique release device shifted by the prey to reach the } \\
\text { bait }\end{array}$ & 2 & - & - & - & - & 2 & 2 \\
\hline $\mathrm{D}$ & with bait; the prey tries to separate the bait from the release device & 9 & 2 & 1 & 3 & - & 3 & 9 \\
\hline & no bait, no snare; the prey displaces the release device & 5 & - & - & 4 & 3 & - & 7 \\
\hline $\mathrm{F}$ & no release device & 4 & 1 & 2 & 1 & 1 & 1 & 6 \\
\hline Total & 6 & 33 & 13 & 5 & 8 & 9 & 9 & 44 \\
\hline \multicolumn{2}{|c|}{${ }^{\dagger}$ refer to Fig. 8 for illustration } & \multirow{6}{*}{\multicolumn{7}{|c|}{$\begin{array}{l}\text { Traps known in } 1905(\mathrm{a}+\mathrm{b}+\mathrm{c}+\mathrm{d})=35 \\
\text { Traps known in } 1990(\mathrm{a}+\mathrm{b}+\mathrm{c}+\mathrm{e})=35 \\
\text { Traps in effective use in } 1990(\mathrm{a}+\mathrm{b}+\mathrm{e})=27 \\
\text { Traps common to both periods }(\mathrm{a}+\mathrm{b}+\mathrm{c})=26\end{array}$}} \\
\hline a for & mer trap still currently used & & & & & & & \\
\hline $\mathrm{b}$ for & mer trap and regressing in use & & & & & & & \\
\hline c for & mer trap still known but abandoned & & & & & & & \\
\hline d for & mer trap no longer known & & & & & & & \\
\hline e toc & lay's trap not reported before & & & & & & & \\
\hline
\end{tabular}

shotguns. In a Fang village where hunters are clearly engaged in commercial hunting but still continue tracking game for their domestic consumption, these percentages reveal that: (1) firearms proportionally contribute more to bushmeat trade than any other hunting instrument; (2) the richer hunters are those who, even occasionally, use a firearm; (3) shotguns kill the largest mammals; (4) larger game killed with a shotgun is more likely to be sold than smaller ones. To summarize, large mammals, which form the cohort of most endangered forest species, are those that pay the heaviest price for the trivialized use of firearms in the context of increasing commercial hunting. These results are congruent with data collected among other Fang communities (Fa et al. 2000, 2001, 2002, Keylock 2002, Kümpel et al. 2008, 2010), and most recent studies throughout the Congo Basin confirm that a greater fraction of local hunters now commonly have access to shotguns.

\section{Trapping}

A few authors (Bahuchet and Pujol 1975, Jamin 1979, Dounias 1993) have revived the outdated French expression "ceptologie" (Bulliard 1794) that separates trapping from other forms of cynegetic practices; the interest of trapping lies in a maximal distance between man and the game animal. This term takes its origin from the Latin verb caperé, "to capture" (if prefixed with anle or cum the verb takes two different respective meanings "to anticipate" and "to conceive"). Ceptologie refers to the conception of an assembling that is pending on the interception of a game by anticipation of its movement (Grimblot 1902). The primary efficiency of trapping lies in the effective or apparent absence of the trapper. The etymological root of the Fang term "lām (ò-/mì-)" for trap subtly enlightens their own philosophical perception of trapping: the radical "lā" means "to gather under a precise purpose". The same radical is found, i.e., in "à.lān", a generic name for a group of trees, which include Magnistipula sp. (Chrysobalanaceae), Campylospermum glaucum (Ochnaceae), Hylodendron gabunense (Caesalpiniaceae), among others, and which share the common architectural feature of possessing verticilate leaves bundled at the periphery of the corona. Likewise, the Fang argue that a genuine trapper must bundle a sophisticated assembling, a high technical aptitude and an advanced knowledge of game ecology and behavior.
Following the trap classification elaborated by Bahuchet and Pujol (1975), we identified six basic systems that entail the overall diversity of the traps conceived by Fang. The key principles for each of these systems are detailed in Table 1, and are visualized in Figure 8. Among these six basic systems, 33 different types of traps were inventoried. Secondary modifications that do not alter the general functioning of a type were described as variants within a given type. In total, 44 variants were reported to have existed or to be currently in use among the Fang of southern Cameroon. Such trap diversity is higher than the diversity documented for other Congo Basin forest dwellers, which are renowned for excelling in trapping (Koch 1968, Bahuchet and Pujol 1975, Dupré 1976, Sato 1983, Noss 2008).

Fig. 8. Basic systems of Fang traps (please refer to Table 1 for respective descriptions)
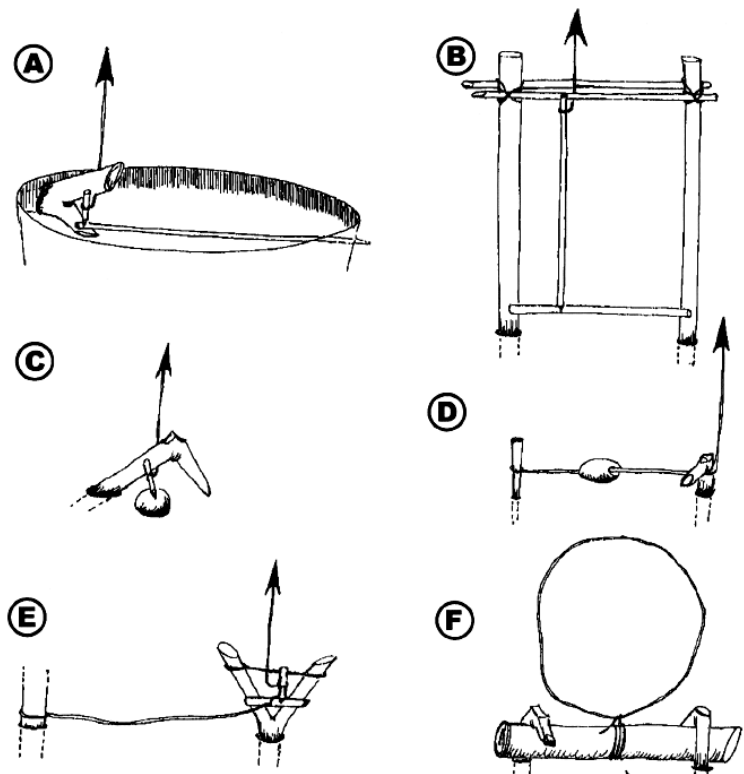

(F)

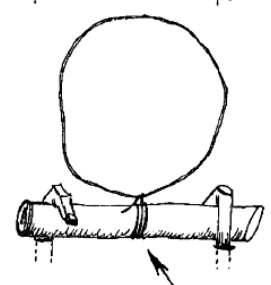


Fig. 9. Compared mechanical typology of traps between 1905 and 1990

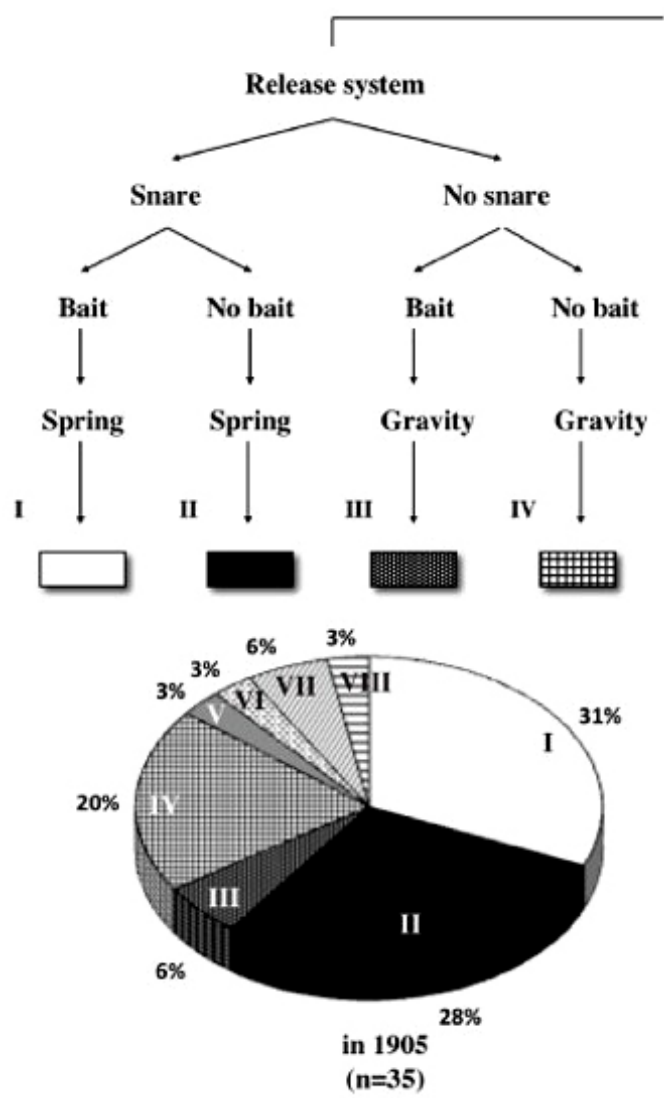

Trap
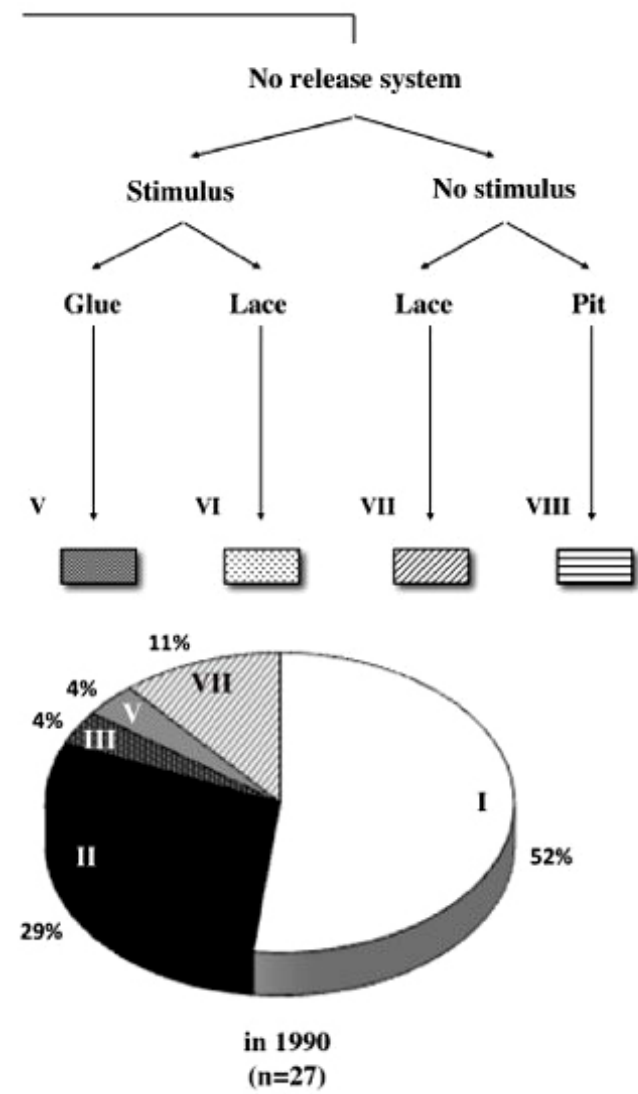

Table 1 provides a distribution of the 44 variants according to their resilience of knowledge and use. As far as the sphere of knowledge is concerned, it appears from this table that the number of trap variants was the same in 1905 as in 1990 (35 variants). Twenty-six variants were commonly known in both periods. But when considering only the effective use of known traps, a significant drop is registered from 1905 (35 variants) to 1990 (27 variants). In the meantime, the Fang adopted nine new traps, but these recent acquisitions correspond neither to new systems nor to new types. Far from revealing a profound technological revolution of trapping, these new traps correspond only to variants that rather express modest adaptations of the Fang trapping technology. However, available sources do not enable us to clarify the origin of these new variants.

Figure 9 is a tree-structured figure that provides a slightly different perspective of the evolution of Fang trapping as it focuses on the mechanical principles of the effectively used traps. This typology shows a significant impoverishment of trap mechanisms (eight in 1905 versus five in 1990) and a pronounced tendency for homogenization resulting from the massive use of snare traps. Snares intervened in 59\% of the traps described by Tessmann; 85 year later, their predominance had risen to $81 \%$. Such hegemony of snares and the induced loss in trap technology are indisputable signs of the fairly recent involvement of the Fang trappers in the bushmeat trade.
The popularity of snares, be they with or without baits, is due to the proliferation of twisted wire cable. Commonly called "wàyà", a pidgin corruption of wire, this cable is furnished at a negligible price in any remote stall, although it is officially banned by national wildlife codes throughout the Congo Basin (Noss 1998). The cable can be untwisted or augmented until obtaining the appropriate section in accordance with the size of the targeted game. Wire cable was introduced after the Second World War and irremediably replaced fiber cords that were too sensitive to high forest hygrometry, and elephant hair whose resistance allowed only small game quarries. Rattan snares are still in use for small prey such as rodents (rats, squirrels, flying squirrels, giant rats) and Guinea fowls. As mentioned by several authors (for instance, Dounias 2000, Lupo and Schmitt 2002, Noss 2008), cable snares are indiscriminate. The fact that they can capture virtually every mammal species in a nonselective manner explains that cable adoption has led to an impoverishment of trapping technology.

The reasons for the abandonment of three out of eight trap mechanisms by the Fang are socio-cultural. Discarded traps are those that are now judged too dangerous for the villagers themselves and for the growing number of outsiders circulating in the forest: pit traps sometimes completed by impaling wooden stakes, elephant traps using spears, bush-pig traps composed of falling trunks. Furthermore, these traps required some sort of collaboration among trappers, and were a means to establish 
peaceful relationships within communities. Their extinction accompanied the renouncement of communal net and pursuit hunting. Nowadays, trapping has become an intrinsic individualistic activity. Even when residing in collective camps, trappers now set up and manage their trap lines separately. Commercial trapping has reinforced individualism and encouraged the abandonment of traps that were judged time or manpower consuming. Concomitantly, standardized and indiscriminate snares have discouraged the installation of the most specific traps.

But let us consider in more detail the two distinct sub-categories of cable snares. Figure 9 shows that the proportion of snare traps without bait has remained the same between the two compared periods of time. This category of snares corresponds to the traps that make up the lines installed in the primary forest. Our own quantitative survey carried out in the 1990s points out that these lines are clearly conceived to supply bushmeat trade; they provide $54 \%$ of the total captured biomass and ensure $59 \%$ of the income from bushmeat. In 1990, a Fang line was on average composed of 70 cable snares, while poachers, who practice hunting as an exclusive activity, could possess more than 300 cable snares (Dounias 2000). Checking all the snares could take up to two days, and the progressive rarefaction of large mammals near villages has pushed trappers to establish their snare lines further away, thus increasing the walking distance between villages and trap lines. After adding the time required to cure the meat in the base camp before returning to the village, five to six days had become the minimum time lapse between two visits. Given such time lapses, the use of bait has inevitably become inappropriate.

As revealed by Figure 9, snare traps including baits form the category that absorbed all the new variants that were conceived after Tessmann's report. Snares with baits differ from other traps on two major aspects: they must be visited and repaired frequently (generally on a daily basis), and they must be discriminative, that is, the use of baits and the way to catch the prey must be adjusted to the specific prey. If one sets aside a few baits that are installed during the night to catch dwarf crocodiles and that were already reported by Tessmann, installation of snares with bait is a diurnal activity that is predominantly carried out within or near villages, in forest edges, agroforests, swiddens, fallows or home gardens. In our 1990s survey, such "garden trapping" (to paraphrase Linares 1976) contributed to only $4 \%$ of the total biomass captured and $2 \%$ of the income generated from bushmeat. In fact, garden trapping is no longer under the control of adults: it has fallen into the exclusive hands of children. Kids are depositories of a specific sphere of trapping knowledge, which is technically speaking the most diversified, and which they manage on their own. The intervention of adults is minimal since this form of trapping takes place in proximity of the safe homestead. The assembling of these traps combines recreational and educative purposes as it prepares budding trappers for adulthood. The bushmeat captured in the vicinity of villages is generally consumed as snack food by children; it incidentally makes up a valuable part of their diet in its own right. Children should not be viewed only as the final beneficiaries of a tradition that should be preserved by any means; they also hold in their hands a corpus of knowledge and know-how that adults no longer care about, and that still could ensure a reliable portion of meat procurement for domestic consumption.

\section{CONCLUSION}

Ethnographic and archive documents and quantitative field surveys were combined to draw a more dynamic picture of the changes and patterns in bushmeat use in the Congo Basin. Revisiting the past should help us better understand how bushmeat procurement in the Congo Basin has evolved over the past century, especially how forest dwellers who originally tracked game to satisfy their domestic needs for meat have become pugnacious commercial hunters. The deliberate focus on technological aspects of hunting and trapping practices offer fruitful ground for combining social and ecological systems in bushmeat research. The exploration of knowledge systems and practices along such a historical perspective may also provide hints on realistic and low-cost pathways to improve hunting management in the near future, besides just increasing the number of armed ecoguards.

Historical narratives by first explorers and detailed ethnographic descriptions transmitted by Tessmann tell us that trapping was already a prominent cynegetic activity in the $19^{\text {th }}$ century, and that trapping technology has not radically changed. A few traps requiring partnership for their assembling disappeared because they became inappropriate in pacified and sedentarized conditions. Snare traps already formed a significant part of the trapping technology range. With the recent advent of twisted wire cable, snares have become increasingly prey indiscriminate, easier and faster to install, and they noticeably degraded the local art of trapping. Nevertheless, knowledge of snare traps with bait has remained vivid and even increased. Traps using baits are significantly more sophisticated to assemble, their use must be adjusted to each targeted game, and the bait requires frequent visits. These traps provide less productive return with regard to the time and energy invested and they essentially form part of subsistence meat procurement that is now under the responsibility of children. Nevertheless, the persistence of this technology is a precious opportunity to sustain traditional garden hunting and to experiment with new wildlife farming initiatives. It is now widely admitted that anthropophilous mammals, such as large rodents or the dwarf antelope (Neotragus batesi, Bovidae), which tolerate the proximity of humans and find appropriate reproductive conditions in anthropogenic forests (fallows, agroforests, home gardens), can meet the domestic needs for bushmeat and therefore reduce the hunting pressure on more endangered game species (Ntiamoa-Baidu 1997).

Projectile weapons primarily served for war. The common use of crossbows as a hunting weapon was relatively ephemeral as it required the adoption of a new type of poison (ptomains being replaced by Strophantus seeds). It was progressively relegated to Pygmies before being wiped out by the increased adoption of shotguns. It was only between the two World Wars and long after the pacification and the fixation of Pahouin migration that shotguns, which had been massively imported in the African continent since the 1850 s, became efficient and affordable hunting weapons. Their decisive upsurge as the principal killing instrument for bushmeat procurement only dates back to the 1970s, since the advent of flashlights allowing night hunting. The engagement of traditional subsistence hunters in the bushmeat trade and the induced drastic depletion of forest game are the result of the successive occurrence of cable snares and night 
hunting with shotguns that arose during the period of independence of most central African countries between the late 1950s and the early 1970s. Past hunting was an art that required real expertise and knowledge about wildlife biology, ecology, and ethology. Firearms, flashlights, and cable snares are open cynegetic activities to neophytes; hunting skills and cultural values consequently fell by the wayside. Eliciting traditional ecological knowledge in the international forum should be a nonnegligible opportunity to polish the image of traditional hunting expertise, hence encouraging local communities to come back to more conservative and noble hunting practices that would therefore slow down the expansion of indiscriminate overhunting.

Collective hunting expeditions (pursuit hunting with hounds and, most importantly, net hunting) were mainly motivated by sociopolitical considerations that became obsolete after the termination of ancestral migrations. Like crossbow hunting, they rapidly became Pygmy exclusivities. As was reported from various parts of the Congo Basin, Pygmies tend to become experts in using techniques or producing materials that are crucial for the maintenance of their hunting and gathering way of life, but that they formerly borrowed from their non-Pygmy neighbors. In the context of increased pressure on extensively fragmented forestlands, tenurial arrangements between communities are becoming more difficult to achieve. The revival of collective and socio-political hunting expeditions in politically neutral forest patches (similar to past ò.kày) could be a valuable way to rehabilitate some sort of mutual cohesion that could help prevent land access conflicts between neighboring villages, lineages, or ethnic groups. A revived collectivistic approach to hunting as a socio-political regulation process would also mitigate the individualistic propensity to hunt just for money. The neglect of all collective forms of hunting and trapping, along with the proliferation of shotguns and the intensification of cable snare lines clearly represent an expression of greater individualism among local hunters. Any regulation of bushmeat trade is harder to implement since this trade is built upon a juxtaposition of individualist shooters who have lost the social and cultural fundamentals of an ancient and collectivist manner of hunting. There is some ambivalent irony in noticing that children are the last practitioners of this art in distress.

Responses to this article can be read online at: http://www.ecologyandsociety.org/issues/responses. $\mathrm{php} / 7946$

\section{Acknowledgments:}

I am grateful to the Fang sub-group communities that welcomed me and actively contributed to this study. This research was carried out with the financial support of IRD and CNRS, in close partnership with the Cameroonian Ministry of Research and Higher Education. I acknowledge the CIFOR Bushmeat Research Initiative for encouraging me to contribute to this special feature on bushmeat in Ecology and Society. I also wish to thank the anonymous reviewers for their useful comments on the drafts of the manuscript, which helped me to significantly improve the final version of this paper.

\section{LITERATURE CITED}

Alexandre, P., and J. Binet. 1958. Boulou, Béti, Fang. Le groupe dit Pahouin. Presses Universitaires de France, Paris, France.

Alexandre, P. 1965. Protohistoire du groupe beti-bulu-fang: essai de synthèse provisoire. Cahier d'Études Africaines 5(20):503-560. http://dx.doi.org/10.3406/cea.1965.3049

Assoumou, J. 1977. L'économie du cacao. Delarge, Paris, France.

Bahuchet, S. 1987. Le filet de chasse des Pygmées Aka (République Centrafricaine). Pages 209-226 in B. Koechlin, F. Sigaut, J.M.C. Thomas, and G. Toffin, editors. De la voûte célèste au terroir, du jardin au foyer : mosaïque sociographique. École des Hautes Études en Sciences Sociales, Paris, France.

Bahuchet, S., and R. Pujol. 1975. Étude ethnozoologique de la chasse et des pièges chez les Isongo de la forêt centrafricaine. Pages 181-192 in L'Homme et l'animal, premier colloque d'ethnozoologie. Institut International d'Ethnosciences, Paris, France.

Bailey, R. C., and R. Aunger, Jr. 1989. Net hunters vs. archers: variation in women's subsistence strategies in the Ituri forest. Human Ecology 17(3):273-297. http://dx.doi.org/10.1007/ $\underline{\mathrm{BF} 00889020}$

Bakarr, M. I., G.A.B. da Fonseca, R. A. Mittermeier, A. B. Rylands, K. Walker Painemilla, editors. 2001. Hunting and bushmeat utilization in the African rain forest. Perspectives toward ablueprint for conservation action. Center for Applied Biodiversity Science, Washington, D.C., USA.

Balfour, H. 1909. The origin of West African crossbows. Journal of the African Society 8(32):337-356.

Bostoen, K., B. Clist, C. Doumenge, R. Grollemund, J.-M. Hombert, J. K. Muluwa, and J. Maley. 2015. Middle to late Holocen paleoclimatic change and the early Bantu expansion in the rain forests of western Central Africa. Current Anthropology 56(3):354-384. http://dx.doi.org/10.1086/681436

Bulliard, P. 1794. Aviceptologie française ou traité général de toutes les ruses dont on peut se servir pour prendre les oiseaux qui sont en France. Cussac, Paris, France.

Cadet, X. 2009. Histoire des Fang, peuple gabonais. L'Harmattan, Paris, France.

Chamberlin, C. 1978. The migration of the Fang into Central Gabon during the nineteenth century: a new interpretation. International Journal of African Historical Studies 11(3):429-456. http://dx.doi.org/10.2307/217312

Chardonnet, P. editor. 1995. Faune sauvage africaine. La ressource oubliée. Communautés Européennes, Bruxelles, Belgique.

Colell, M., C. Maté, and J. E. Fa. 1994. Hunting among Moka Bubis in Bioko: faunal exploitation at the village level. Biodiversity and Conservation 3:939-950. http://dx.doi.org/10.1007/BF00129668

Compiègne, V. (Marquis de). 1875. L'Afrique Equatoriale. Gabonais, Pahouins, Gallois. Plon, Paris, France.

Dounias, E. 1993. Dynamique et gestion différentielles du système de production des Mvae du sud Cameroun forestier. Dissertation. Université des Sciences et Techniques du Languedoc, Montpellier, France. 
Dounias, E. 1996a. Agriculture des Mvae du sud Cameroun littoral forestier: étude dynamique des composantes de l'agroécosystème et des plantes cultivées alimentaires. Pages 155-172 in A. Froment, I. de Garine, and C. Binam Bikoï, editors. Anthropologie alimentaire et développement en Afrique intertropicale : du biologique au social. ORSTOM-l'Harmattan, Paris, France.

Dounias, E. 1996b. Recrûs forestiers post-agricoles: perceptions et usages chez les Mvae du sud Cameroun. Journal d'Agriculture Traditionnelle et de Botanique Appliquée 38(1):153-178. http://dx. doi.org/10.3406/jatba.1996.3592

Dounias, E. 2000. Le câble pris au piège du conservateur, technologie du piégeage et production cynégétique chez les Mvae du sud Cameroun forestier. Pages 281-300 in S. Bahuchet, D. Bley, H. Pagezy, and N. Vernazza-Licht, editors. L'Homme et la forêt tropicale. Editions de Bergier, Châteauneuf de Grasse, France.

Dounias, E. 2010. An ounce of prevention is worth a pound of cure. Fang homegarden organization as a means to prevent health risks. The Open Complementary Medicine Journal 2010(2):31-41.

Dounias, E., and S. Bahuchet. 2000. Habitat semi-permanent en forêt d'Afrique Centrale. Pages 161-181 in B. Brun, A.-H. Dufour, B. Picon, and M.-D. Ribéreau-Gayon, editors. Cabanes, cabanons et campements. Formes sociales et rapports à la nature en habitat temporaire. Éditions de Bergier, Châteauneuf de Grasse, France.

Dounias, E., and C.-M. Hladik. 1996. Agroforêts mvae et yasa du Cameroun littoral: fonctions et structures. Pages 1103-1126 in C.-M. Hladik, A. Hladik, H. Pagezy, O. F. Linares, G. J. A. Koppert, and A. Froment, editors. L'alimentation en forêt tropicale: interactions bioculturelles et applications au développement. Unesco-Parthenon, Paris, France.

Dounias, E., and C. Leclerc. 2006. Spatial shifts and migration time scales among the Baka Pygmies of Cameroon and the Punan of Borneo. Pages 147-173 in W. de Jong, L. Tuck-Po, and A. Kenichi, editors. The social ecology of tropical forest: migration, populations and frontiers. Kyoto University Press and Trans Pacific Press, Kyoto, Japan.

Du Chaillu, P. 1856. Voyages et aventures en Afrique Equatoriale. Mours et coutumes des habitants, chasses au gorille, au crocodile, au léopard, à l'éléphant, à l'hippopotame. M. Levy, Paris, France.

Dupré, G. 1976. La chasse au filet chez les Nzabi (République Populaire du Congo). ORSTOM Série Sciences Humaines 13 (4):343-355.

Dupré, G. 1982. Un ordre et sa destruction. Editions de l'ORSTOM, Paris, France.

Dwyer, P. D. 1983. Etolo hunting performance and energetics. Human Ecology 11:145-174. http://dx.doi.org/10.1007/BF00891741

Fa, J. E. 2000. Hunted animals in Bioko Island, West Africa: sustainability and future. Pages 168-198 in J. G. Robinson, and E. Bennett, editors. Hunting for sustainability in tropical forests. Columbia University Press, New York, USA.

Fa, J. E., J. E. Garcia Yuste, and R. Castelo. 2000. Bushmeat markets on Bioko Island as a measure of hunting pressure. Conservation Biology 14:1602-1613. http://dx.doi.org/10.1111/ j.1523-1739.2000.99067.x
Fa, J. E., J. Juste, R. W. Burn, and G. Broad. 2002. Bushmeat consumption and preferences of two ethnic groups in Bioko islands, West Africa. Human Ecology 30(3):397-416. http://dx.doi. org/10.1023/A:1016524703607

Faure, J. 2002. L'Arsenal de Paris: histoire et chroniques. L'Harmattan, Paris, France.

Fimbel, R. A., A. Grajal, and J. G. Robinson, editors. 2001. The cutting edge. Conserving wildlife in logged tropical forests. Columbia University Press, New York, USA.

Greaves, R. D. 1997. Hunting and multifunctional use of bows and arrows. Pages 287-320 in H. Knecht, editor. Projectile technology. Plenum, New York, USA. http://dx.doi. org/10.1007/978-1-4899-1851-2 12

Grenand, P. 1995. De l'arc au fusil. Un changement technologique chez les Wayãpi de Guyane. Pages 23-52 in F. Grenand, and V. Randa, editors. Transitions plurielles. Exemples dans quelques sociétés des Amériques. Peeters, Paris, France.

Grimblot, L. 1902. Vocabulaire synthétique de la langue française. Etymologie, lexique et graphique. Larousse, Paris, France.

Guthrie, M. 1967. Comparative bantu: an introduction to the comparative linguistics and prehistory of the Bantu languages. Gregg, London, UK.

Hames, R.B. 1979. A comparison of the efficiencies of the shotgun and the bow in neotropical forest hunting. Human Ecology 7:219-252. http://dx.doi.org/10.1007/BF00889493

Harako, R. 1981. The cultural ecology of hunting behavior among Mbuti pygmies in the Ituri forest, Zaire. Pages 499-555 in R. S. Harding, and G. Teleki, editors. Omnivorous Primates. Columbia University Press, New York, USA.

Ichikawa, M. 1983. An examination of the hunting-dependent life of the Mbuti pygmies, eastern Zaire. African Study Monographs 4:55-76. http://dx.doi.org/10.14989/68001

Infield, M. 1988. Hunting, trapping and fishing in villages within and on the periphery of the Korup National Park. Korup National Park Socioeconomic Survey, Paper nĚ6. World Wide Fund for Nature, Gland, Switzerland.

Jamin, J. 1979. La tenderie aux grives chez les Ardennais du Plateau. Mémoires de l'Institut d'Ethnologie, Paris, France.

Keylock, N. 2002. The importance of hunting for bushmeat to a rural community in Equatorial Guinea. Thesis. Imperial College of Science, Technology and Medicine, London, UK.

Knecht, H., editor. 1997. Projectile technology. Plenum, New York, USA. http://dx.doi.org/10.1007/978-1-4899-1851-2

Koch, H. 1968. Magie et chasse dans la forêt camerounaise. Berger Levrault, Paris, France.

Kümpel, N. F., E. J. Milner-Gulland, G. Cowlishaw, and J. M. Rowcliffe. 2010. Incentives for hunting: the role of bushmeat in the household economy in rural Equatorial Guinea. Human Ecology 38:251-264. http://dx.doi.org/10.1007/s10745-010-9316-4

Kümpel, N. F., E. J. Milner-Gulland, J. M. Rowcliffe, and G. Cowlishaw. 2008. Impact of gun-hunting on diurnal primates in continental Equatorial Guinea. International Journal of Primatology 29:1065-1082. http://dx.doi.org/10.1007/s10764-008-9254-9 
Laburthe-Tolra, P. 1981. Les seigneurs de la forêt-essai sur le passé historique, l'organisation sociale et les normes ethniques des anciens Beti du Cameroun. Sorbonne, Paris, France.

Laburthe-Tolra, P. 1985. Initiations et sociétés secrètes au Cameroun. Essai sur la religion beti. Khartala, Paris, France.

Leroi-Gourhan, A. 1945. Evolution et technique. II: Milieu et techniques. Albin Michel, Paris, France.

Linares, O. F. 1976. "Garden hunting" in the American tropics. Human Ecology 4(4):331-349. http://dx.doi.org/10.1007/bf01557917

Lupo, K. D., and D. N. Schmitt. 2002. Upper paleolothic nethunting, small prey exploitation, and women's work effort: a view from the ethnographic and ethnoarchaeological record of the Congo Basin. Journal of Archeological Method and Theory 9 (2):147-179. http://dx.doi.org/10.1023/A:1016578224794

Mbenkum, F. T., and D. N. Thomas. 1992. Sustainable harvest of secondary products aimed at easing timber exploitation from Cameroon's forests: a survey of medicinal, insecticidal and molluscicidal plants. Pages 251-262 in M. D Kabala, J. Bedel, and T. Njine, editors. Gestion des ressources de la biosphère et éducation relative à l'environnement. Unesco, Paris, France.

Mboyi Moukanda, L. C. 2013. La pratique des échanges commerciaux dans la société précoloniale du Gabon: XVIe-[XIXe] siècles. Dissertation. Université Michel de Montaigne - Bordeaux III, Bordeaux, France.

Meijaard E., D. Sheil, R. Nasi, D. Augeri, B. Rosenbaum, D. Iskandar, T. Setyawati, M. Lammertink, I. Rachmatika, A. Wong, T. Soehartono, S. Stanley, and T. O'Brien. 2005. Life after logging. Reconciling wildlife conservation and production forestry in Indonesian Borneo. Center for International Forestry Research (CIFOR), Bogor, Indonesia.

Moulton, M. O., and J. Sanderson, editors. 1999. Wildlife issues in a changing world. Lewis, London, UK.

Nasi, R., A. Taber, and N. van Vliet. 2011. Empty forests, empty stomachs? Bushmeat and livelihoods in the Congo and Amazon Basins. International Forestry Review 13(3):355-368. http://dx.doi. org/10.1505/146554811798293872

Nekes, H. 1875. Vier Jahre im Kameruner Hinterland. Verlag und Druck der Kongregation der Pallotinner, Limburg, Germany.

Nelleman, C., I. Redmond, and J. Refish, editors. 2010. The last stand of the gorilla. Environmental crime and conflict in the Congo Basin. A rapid response assessment. United Nations Environment Programme, GRID-Arendal, Arendal, Norway.

Noss, A. J. 1995. Duikers, cables, and nets: cultural ecology of hunting in a Central African forest. Dissertation. University of Florida, Gainesville, Florida, USA.

Noss, A. J. 2008. The impacts of cable snare hunting on wildlife populations in the forests of the Central African Republic. Conservation Biology 12(2):390-398. http://dx.doi.org/10.1111/ j.1523-1739.1998.96027.x

Ntiamoa-Baidu, Y. 1997. Wildlife and food security in Africa. FAO Conservation Guide 33, Rome, Italy.

Ohigashi, H., M. Kaji, J. Hoshino, J. Jato, and K. Koshimizu. 1987. The search for useful plants in the tropical rain forest of
Cameroon and the biological activities of these plants. Kyoto University, Kyoto, Japan. http://dx.doi.org/10.11619/africa1964.1987.1

Panyella, A. 1959. Esquema de etnologia de los Fang ntumu. Archivos del Instituto de Estudios Africanos, Madrid, Spain.

Rambo, A. T. 1978. Bows, blowpipes and blunderbusses: ecological implications of weapons change among the Malaysian Negritos. The Malayan Nature Journal 32(2):209-216.

Redford, K. H. 1992. The empty forest. Bioscience 42:12-422. http://dx.doi.org/10.2307/1311860

Redmond, I., T. Aldred, K. Jedamzik, and M. Westwood. 2006. Recipes for survival: controlling the bushmeat trade. Report by the World Society for the Protection of Animals, London, UK.

Reynolds, J. D., G. M. Mace, K. H. Redford, and J. G. Robinson, editors. 2001. Conservation of exploited species. Cambridge University Press, Cambridge, UK.

Robinson, J. G., and E. L. Bennett, editors. 2000. Hunting for sustainability in tropical forests. Columbia University Press, New York, USA.

Roth, R. 1992. Histoire de l'archerie, arc et arbalète. Max Chaleil, Montpellier, France.

Sakanashi, K. 2011. Land use patterns for cacao agroforestry in southern Cameroon. African Study Monographs 32(4):135-155. http://dx.doi.org/10.1111/10.14989/151328

Sato, H. 1983. Hunting of the Boyela, slash-and-burn agriculturalists in the central Zaire forest. African Study Monographs 4:1-54. http://dx.doi.org/10.14989/68002

Savorgnan de Brazza, P. 1888. Conférences et lettres de $P$. Savorgnan de Brazza dans l'ouest africain (1875-1887). M. Dreyfous, Paris, France.

Terashima, H. 1983. Mota and other hunting activities of the Mbuti archers: a socio-ecological study of subsistence technology. African Study Monographs 3:71-85. http://dx.doi.org/10.14989/67990

Tessmann, G. 1913. Die Pangwe- völkerkundliche Monographie eines westafrikanischen Negerstammes. Ergebnisse des Lübecker Pangwe-expedition 1907-1909 und früherer Forschungen 1904-1907. Ernst Wasmuth, Berlin, Germany.

Touchard, F. 1861. Notice sur le Gabon. Revue Maritime et Coloniale octobre 1861:1-17.

Trenning, R. 1998. Spatial distribution of trapping: the case of Nyangong a Bantu village in the South Province of Cameroon. Thesis. International Agricultural College Larenstein, Arnhem, the Netherlands.

Wilkie, D. S., and J. F. Carpenter. 1999. Bushmeat hunting in the Congo Basin: an assessment of impacts and options for mitigation. Biodiversity and Conservation 8(7):927-955. http://dx. doi.org/10.1023/A:1008877309871

Wilkie, D. S., and B. Curran. 1991. Why do Mbuti hunters use nets? Ungulate hunting efficiency of archers and net hunters in the Ituri rainforest. American Anthropologist 93(3):680-689. http://dx.doi.org/10.1525/aa.1991.93.3.02a00080 
Wolfe, N. D., A. T. Prosser, J. K. Carr, U. Tamoufe, E. MpoudiNgole, J. N. Torimiro, M. LeBreton, F. E. McCutchan, D. L. Birx, and D. S Burke. 2004. Exposure to nonhuman primates in rural Cameroon. Emerging Infectious Diseases 10:2094-2099. http://dx. doi.org/10.3201/eid1012.040062

Yost, J. A., and P. M. Kelley. 1983. Shotguns, blowguns, and spears: the analysis of technological efficiency. Pages 189-224 in R. B. Hames, and W. T. Vickers, editors. Adaptive responses of native Amazonians. Academic, New York, USA. http://dx.doi. org/10.1016/b978-0-12-321250-4.50010-5 